\title{
TOXIC EFFECTS AND BIOACCUMULATION OF HEAVY METALS ON ANAEROBIC CILIATES ISOLATED FROM ANAEROBIC REACTORS
}

\author{
M. PRIYA ${ }^{\mathrm{a} 1}$ AND V.B. MANILAL ${ }^{\mathrm{b}}$

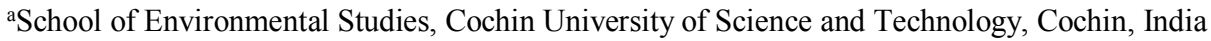 \\ ${ }^{\mathrm{b}}$ Process Engineering and Environmental Technology Division, National Institute for Interdisciplinary Science and Technology, CSIR, \\ Thiruvananthapuram, India
}

\begin{abstract}
Anaerobic ciliates isolated from reactors fed with diary wastewater and studied the toxic effect of the heavy metals on ciliates. The order of toxicity of selected heavy metals on ciliates was $\mathbf{C d}>\mathbf{C u}>\mathbf{P d}>\mathbf{C r}>\mathrm{Zn}$. Cd was highly toxic to protozoa and zinc was the least, tolerant up to $120 \mathrm{mg} \mathrm{l}^{-1}$. Linear regression analysis carried out to detect the median lethal concentration (LD $\left.\mathrm{L}_{50}\right)$ of heavy metals and it was different for different heavy metals. Further, bioaccumulation of heavy metals in ciliates was con firmed by using specific fluorophore. to The result indicates that anaerobic ciliates can be used as potential cell biosensors for assessing heavy metal pollution in wastewater.
\end{abstract}

KEYWORDS: Anaerobic ciliates, Heavy metals, Toxicity, Bioaccumulation

Wastewater provides an ideal growth medium for many groups of organisms and growth of these organisms play key roles in the process of purification through biodegradation. However, in recent years heavy metals are persistent in wastewater, they are not biodegradable and their toxicity, especially in high concentrations, has become a global issue (Jern, 2006). They are toxic to most microorganisms at specific concentrations and often reducing the efficiency of biological wastewater treatment due to sludge in toxication (Battistoni et al.,, 1993, Artola et al.,, 1997). At the same time, several microorganisms are used for heavy metal detoxification process in wastewater systems (Madoni et al.,, 1996, Rehman et al., 2007, Bestawy et al.,, 2013, Gupta et al., 2015). The ability of anaerobic protozoa in terms of resistance to and the bioaccumulation of heavy metals have been rarely documented in anaerobic environments (Ivan et al., 1986, Kisidayova et al., 2000, Katarina et al., 2009).

Anaerobic ciliates are widely distributed in anaerobic systems and they form an important link in anaerobic microbial food webs even when appearing in low abundance (Fenchel and Finlay, 1991, Priya et al., 2007a).High turnover rates and short generation times allow many protozoa species to respond immediately to changing environmental conditions (Fenchel, and Finlay, 1995). Thus, ciliates may be sensitive and highly valuable bioindicator organisms in anaerobic environments (Fenchel and Finlay, 1991). Studies have revealed that aerobic protozoa can resist the toxicity of heavy metals even at high concentrations through the acquisition of specific resistance systems (Madoni et al., 1996, Shakoori et al., 2004, Dan et al., 2006). The aim of this study was to evaluate the cytotoxic effect and bioaccumulation of heavy metals $\mathrm{Cd}$, $\mathrm{Zn}, \mathrm{Pb}, \mathrm{Cr}$ and $\mathrm{Cu}$ by anaerobic ciliates isolated from anaerobic reactors.

\section{MATERIALS AND METHODS}

Anaerobic ciliates were isolated from laboratory scale bioreactor fed on dairy wastewater (Priya et al., 2007b). The toxic effect of heavy metals on anaerobic ciliates was studied by introducing $\mathrm{Cd}, \mathrm{Zn}, \mathrm{Pb}, \mathrm{Cr}$, and $\mathrm{Cu}$. Ciliates were exposed to different concentrations of metals such as $\mathrm{Cd}, \mathrm{Zn}, \mathrm{Pb}, \mathrm{Cr}$ and $\mathrm{Cu}$ in serum vials with an active volume of $10 \mathrm{ml}$. The vials were incubated at $30^{\circ} \mathrm{C}+2$ in triplicates and the mean of results were taken. The response of protozoa was assessed in terms of mortality and survival. The number of survived cells were examined at selected intervals under a microscope. The median lethal concentrations $\left(\mathrm{LC}_{50}\right)$ were calculated from these data. The maximum resistance dose (MRD) of anaerobic protozoa was determined by analyzing statistically significant differences among the concentrations tested.

Bioaccumulation of $\mathrm{Zn}$ in the ciliates was detected by using a specific fluorophore - TSQ ( $N$-(6-methoxy-8quinolyl)-p-toluenesulfonamide) as per the methods described by Ana et al., 2006. The ciliates cultures exposed for $24 \mathrm{~h}$ at sublethal concentrations of Zinc were centrifuged at $3000 \mathrm{rpm}$ for $5 \mathrm{~min}$. Then cells were 
resuspended in Tris- $\mathrm{HCl}$ buffer $0.01 \mathrm{M}(\mathrm{pH} 6.8)$ and fixed with one drop of pure paraformaldehyde. After fixation, cells were washed in the same buffer (Tris-HCl) twice, and then ciliates were exposed to $10 \mu \mathrm{g} \mathrm{ml}^{-1}$ of TSQ for $10 \mathrm{~min}$ (Ana et al., 2006). Observations were made under a Leica DM 2500 fluorescence microscope.

\section{RESULTS AND DISCUSSION}

\section{Effects of Heavy Metals on Ciliates}

The result of maximum resistance dose (MRD) of heavy metal to anaerobic protozoa is given in Table 1 . Copper had the growth inhibition significantly above $13 \mathrm{mg}$ $1^{-1}$. Zinc inhibited the growth of anaerobic protozoa almost completely above $120 \mathrm{mg} \mathrm{l}^{-1}$. Lead inhibited the growth of protozoa above $24 \mathrm{mg} \mathrm{l}^{-1}$ and complete growth inhibition was observed with chromium concentrations above $31 \mathrm{mg} \mathrm{l}^{-}$ ${ }^{1}$. Among the five metals studied, cadmium had maximum toxicity and led to complete inhibition at a concentration of $8 \mathrm{mg} \mathrm{l}^{-1}$ (Table. 1). It is important to note that the organisms may survive on the MRD level when the environmental perturbation or toxic discharge ceases, but they become extinct above the MRD concentration (Walker et al., 2001).

Table 1: Heavy metal resistance of anaerobic protozoa to $\mathrm{Cd}, \mathrm{Zn}, \mathrm{Pd}, \mathrm{Cr}$ and $\mathrm{Cu}$ (expressed as maximum resistance dose - MRD). Values presented are the mean of 4 replicates

\begin{tabular}{|c|c|}
\hline Heavy metals & MRD ( $\left.\mathrm{mg} \mathrm{l}^{-1}\right)$ \\
\hline $\mathrm{Cd}$ & $8+1$ \\
\hline $\mathrm{Cu}$ & $13+1.2$ \\
\hline $\mathrm{Pb}$ & $24+1.5$ \\
\hline $\mathrm{Cr}$ & $31+0.5$ \\
\hline $\mathrm{Zn}$ & $120+2$ \\
\hline
\end{tabular}

Figure 1 illustrates the survival of protozoa cells at different concentrations of heavy metals. Cd was highly toxic to protozoa and zinc was the least, tolerant up to 120 $\mathrm{mg} \mathrm{l}^{-1}$. The order of toxicity of heavy metals for ciliates observed was $\mathrm{Cd}>\mathrm{Cu}>\mathrm{Pb}>\mathrm{Cr}>\mathrm{Zn}$. No previous studies on the toxicity of heavy metals on the protozoan community of anaerobic wastewater treatment systems were found in the literature for comparison. Madoni et al.,, (1996) have documented a slightly different sequence for the heavy metals toxicity to aerobic protozoa of activated sludge and is reported as $\mathrm{Cu}>\mathrm{Hg}>\mathrm{Cd}>\mathrm{Pb}>\mathrm{Cr}>\mathrm{Zn}$. The minimum lethal dose of heavy metals for anaerobic protozoa $\left(\mathrm{LC}_{50}\right)$ was calculated from the regression equation (Figure 1) and the values are shown in Table 2. The effect of heavy metals on protozoan populations have been described in rumen ecosystems (Ivan et al., 1986, Kisidayova et al., 2000, Katarina et al., 2009), and ciliates seems to be more sensitive to heavy metals, probably because ciliates have no cell wall at the trophic stage (Fenchel, and Finlay, 1995).

Table 2: Minimum lethal dose of heavy metals on anaerobic protozoa $\left(\mathrm{LC}_{50}\right)$

\begin{tabular}{|c|c|}
\hline Heavy metals & LC $_{50}\left(\mathrm{mg} \mathrm{l}^{-1}\right)$ \\
\hline $\mathrm{Cd}$ & 4.56 \\
\hline $\mathrm{Cu}$ & 7.79 \\
\hline $\mathrm{Pb}$ & 15.74 \\
\hline $\mathrm{Cr}$ & 19 \\
\hline $\mathrm{Zn}$ & 63.9 \\
\hline
\end{tabular}

\section{Bioaccumulation of Heavy Metals in Ciliates}

Figure 2 shows the presence of dense granules in ciliates exposed with specific fluorophore TSQ. This indicates metal bioaccumulation in the ciliate cytoplasm. It was absent in controls without Zinc. Bioaccumulation of heavy metals seems to be a resistance mechanism of anaerobic ciliates to the metal toxicity. Protozoa are known to involve in the detoxification process of heavy metals in aerobic treatment systems (Madoni et al., 1996). Diaz et al., (2006) observed bioaccumulation of heavy metals as a resistance mechanism in soil protozoa. There is little information available on the mechanisms involved in the heavy metal resistance of anaerobic ciliates.

\section{Morphological Changes and Behavioral Response of Ciliates}

Ciliates exposed to heavy metals showed different behavioural and morphological changes. Addition of heavy metals slow down the movement of ciliate cells and high levels of $\mathrm{Cd}$ arrested the movement of cells. In ciliates, especially exposed with $\mathrm{Cd}, \mathrm{Cu}$ and $\mathrm{Pb}$ cells become more vacuolated and finally lead to death. Ciliates exposed to $\mathrm{Cd}$ above $>8 \mathrm{mg}^{-1}$ developed outwardly protruding vacuole (Figure 3).

The interactions of heavy metals with bacteria and fungi, and aerobic protozoa have been studied in detail (Silver, 1996, Gadd, 1993, Madoni et al., 1996, Cenek et al., 2006) and but rarely studied with respect anaerobic 


\section{PRIYA AND MANILAL: TOXIC EFFECTS AND BIOACCUMULATION OF HEAVY METALS ON ANAEROBIC...}

protozoa. According to Ivan et al., (1986), the rumen ciliate protozoa can reduce the chronic copper toxicity in ruminants by the formation of $\mathrm{CuS}$ in consequence of sulphur amino acid degradation. However, this ability also depends on the biomass of protozoan population (Kisidayova et al., 2000). The presence and activity of microorganisms in biological waste water treatment are
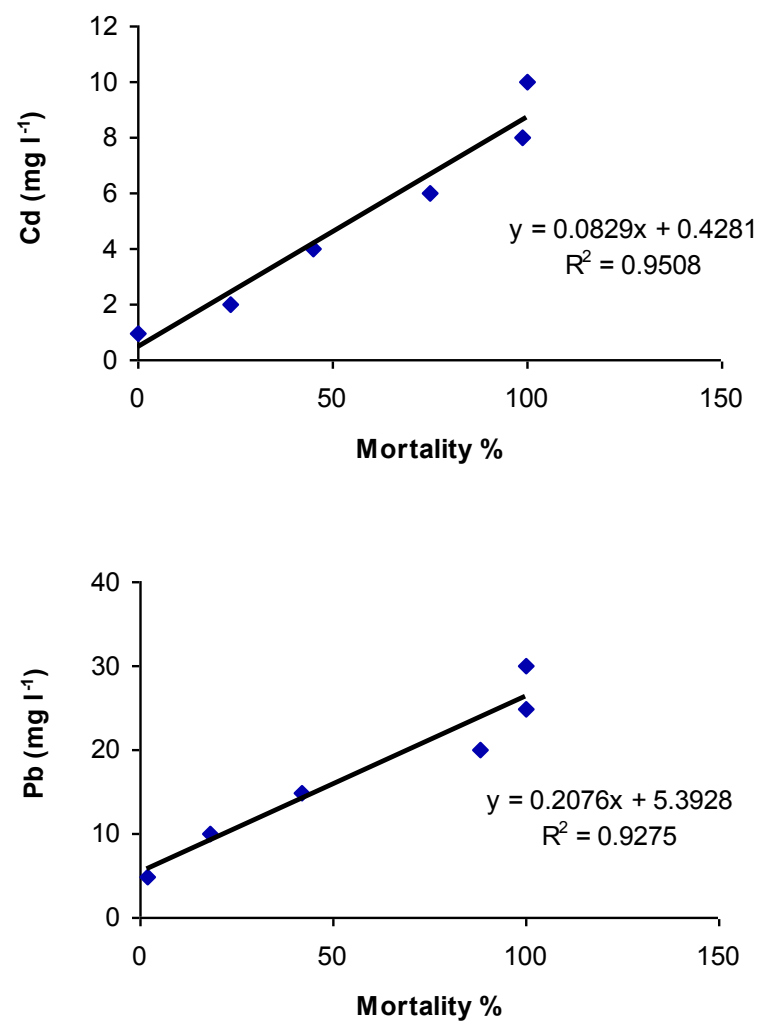

very important and it helps to operate system efficiently. Present studies reveal that anaerobic ciliates are good indicators to detect the toxicity and to determine the bio available concentration of heavy metals. Anaerobic ciliates can be used in the detoxification process of waste water treatment systems for producing of high quality effluent.
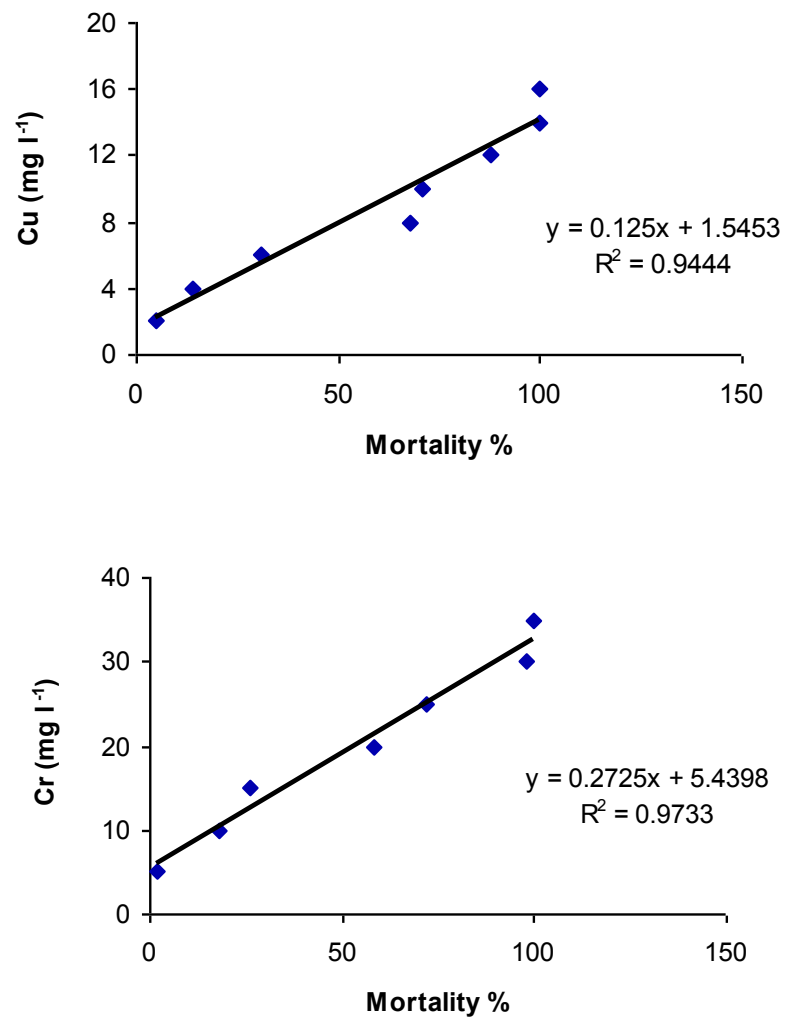

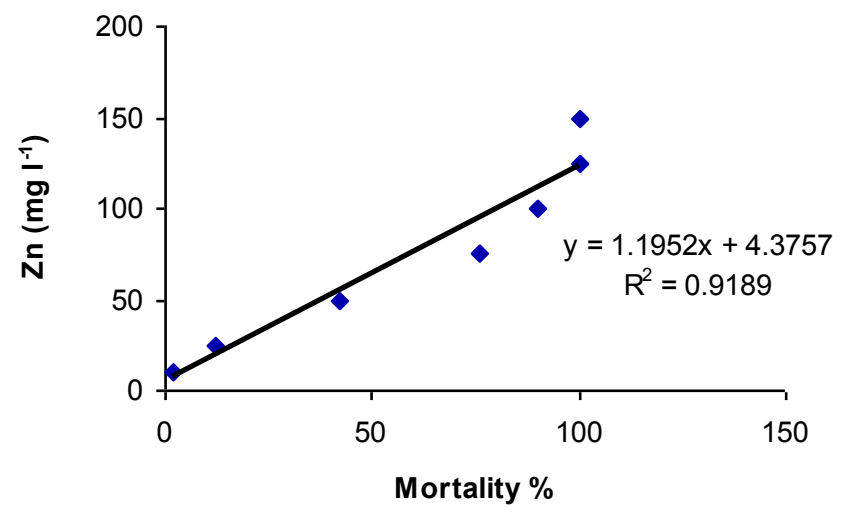

Figure 1: Mortality of protozoa at different concentrations of selected heavy metals 


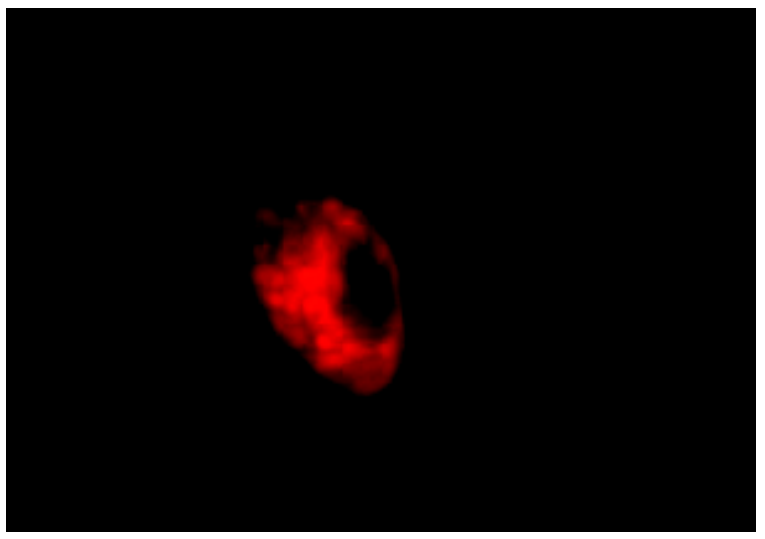

Figure 2: Fluorescence microscopy of $\mathrm{Zn}$ bioaccumulation in the ciliate Prorodon exposed to $\mathrm{Zn}$ $\left(65 \mathrm{mg} \mathrm{l}^{-1}\right)$

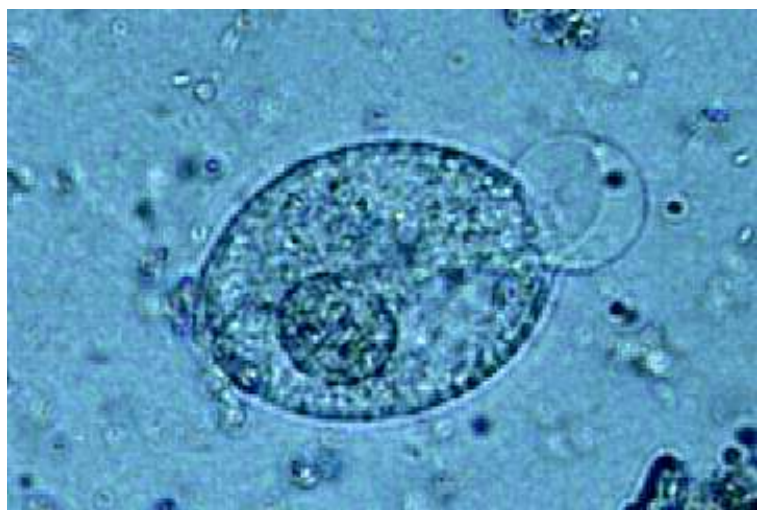

Figure 3: Morphological changes in anaerobic ciliate exposed to $>8 \mathrm{mg} \mathrm{l}^{-1}$ of $\mathrm{Cd}$

\section{ACKNOWLEDGMENTS}

Priya $\mathrm{M}$ acknowledges for the financial assistance from University Grants Commission in the form of a research fellowship (Award No. F 15-6 (Dec 2001)/2002(NET))

\section{REFERENCES}

Ana M.G., Silvia D., Sara B., Andrea G. and Juan C.G., 2006. Cytotoxicity and bioaccumulation of heavy metals by ciliated protozoa isolated from urban wastewater treatment plants. Res. Microbiol., 157:108-118.
Artola A., Balaguer M.D. and Rigola M., 1997. Heavy metal binding to anaerobic sludge. Water Res., 31: 997-1004.

Battistoni P., Fava G. and Ruello M.L., 1993. Heavy metal shock load in activated sludge uptake and toxic effects. Water Res., 27: 821-827.

Cenek N., Nicolina D., Anu K., Katerina M., Marta V., Merja I. and Nelson L., 2006. Comparative use of bacterial, algal and protozoan tests to study toxicity of azo- and anthraquinone dyes. Chemosphere., 63: 1436-1442.

Dan Z., Yi L., Yue Z., Xiao-Juan C. and Yun-Fen S., 2006. Microcalorimetric investigation of the toxic action of $\mathrm{Cr}$ (VI) on the metabolism of Tetrahymenathermophila BF5 during growth. Environ. Toxicol. Pharmaco., 22: 121-127.

Diaz S., Martin-Gonzalez A. and Gutierrez J.C., 2006. Evaluation of heavy metal acute toxicity and bioaccumulation in soil ciliated protozoa. Environ. Int., 32(6): 711-717.

Bestawy E.E., Helmy S., Hussien H., Fahmy M. and Amer R., 2013. Bioremediation of heavy metalcontaminated effluent using optimized activated sludge bacteria. Appl. Water. Sci., 3: 181-192.

Fenchel T. and Finlay B.J., 1991. The biology of free living anaerobic ciliates. Europ. J. Protistol., 26: 201215.

Fenchel T. and Finlay B.J., 1995. Ecology and evolution in anoxic words. University Press, Oxford.

Gadd G.M., 1993. Interactions of fungi with toxic metals. New Phytol., 124: 25-60.

Gupta V.K., Nayak A. and Agarwal S., 2015. Bioadsorbents for remediation of heavy metals: Current status and their future prospects. Environ. Eng. Res., 20: 1-18.

Ivan M., Veira D.M. and Kelleher C.A., 1986. The alleviation of chronic copper toxicity in sheep by ciliate protozoa. British J. of Nutri., 55: 361-361. 
PRIYA AND MANILAL: TOXIC EFFECTS AND BIOACCUMULATION OF HEAVY METALS ON ANAEROBIC...

Jern W.N.G., $2006 . \quad$ Industrial wastewater treatment. Imperial College Press, London.

Kangala B.C., 2003. Accumulation and fate of selected heavy metals in a biological wastewater treatment system, Waste Manage., 23: 135-143.

Katerina M., Zora V., Peter P., Peter J. and Svetlana K., 2009. Tolerance of a ruminant ciliate Entodiniumcaudatum against mercury, copper and chromium. Biologia., 64: 1141-1145.

Kisidayova S., Varyadova Z., Zelenak I. and Siroka P., 2000. Methanogenesis in rumen ciliate cultures of Entodiniumcaudatum and Epidiniumecaudatum after long-term cultivation in a chemically defined medium. Folia Microbiol., 45: 269-274.

Madoni P., Davoli D., Gorbi G. and Vescoli L., 1996. Toxic effects of heavy metals on the activated sludge Protozoan community. Water Res., 30: 135-141.

Priya M., Ajit H. and Manilal V.B., 2007a. Anaerobic protozoa and their growth in biomethanation systems. Biodegradation., 19: 179-185.
Priya M., Ajit H. and Manilal V.B., 2007b. Involvement of protozoa in anaerobic wastewater treatment processes. Water Res., 41: 4639-4645.

Rehman A., Shakoori F.R. and Shakoori A.R., 2007. Multiple metal resistance and uptake by a ciliate, Stylonychiamytilus, isolated from industrial effluents and its possible use in wastewater treatment. Bull. Environ. Contam. Toxicol., 79: $410-414$.

Shakoori A.R., Rehman A. and Haq R.U., 2004. Multiple metal resistances in the ciliate protozoan, Vorticella microstoma, isolated from industrial effluents and its potential in bioremediation of toxic wastes. Bull. Environ. Contam. Toxicol., 72: 1046-1051.

Silver S., 1996. Bacterial metal resistance-a review. Gene., 179: 9-19.

Walker C.H., Hopkin S.P., Sibly R.M. and Peakall D.B., 2001. Principles of ecotoxicology. Taylor and Francis, New York. 